\title{
Impacts of human activities and climate variability on green and blue water flows in the Heihe River Basin in Northwest China
}

\author{
C. Zang ${ }^{1}$, J. Liu ${ }^{1}$, L. Jiang ${ }^{2}$, and D. Gerten ${ }^{3}$ \\ ${ }^{1}$ School of Nature Conservation, Beijing Forestry University, Qinghua East Road 35, \\ Haidian District, Beijing, 100083, China \\ ${ }^{2}$ Institute of Geographic Sciences and Natural Resources Research, Chinese Academy of \\ Sciences, Beijing, 100101, China 11A, Datun Road, Chaoyang District, Beijing, China \\ ${ }^{3}$ Research Domain 1: Earth System Analysis, Potsdam Institute for Climate Impact Research, \\ Telegraphenberg A62, 14473 Potsdam, Germany
}

Received: 3 July 2013 - Accepted: 11 July 2013 - Published: 18 July 2013

Correspondence to: J. Liu (junguo.liu@gmail.com)

Published by Copernicus Publications on behalf of the European Geosciences Union.

9477

\begin{abstract}
Human activities and climate factors both affect the availability of water resources and the sustainability of water management. Especially in already dry regions, water has become more and more scarce with increasing requirements from growing population, economic development and diet shifts. Although progress has been made in understanding variability of runoff, the impacts of climate variability and human activities on flows of both green water (actual evapotranspiration) and blue water (discharge accumulated in the river network) remain less well understood. We study the spatial patterns of blue and green water flows and the impacts on them of human activities and climate 10 variability as simulated by the Soil and Water Assessment Tool (SWAT) for an inland Heihe river basin located in Northwest China. The results show that total green and blue water flow increased from 1980 to 2005, mainly as a result of climate variability (upward precipitation trends). Direct human activities did not significantly change the total green and blue water flow. However, land use change led to a transforma15 tion of 206 million $\mathrm{m}^{3}$ from green to blue water flow, while farmland irrigation expansion resulted in a transformation of 66 million $\mathrm{m}^{3}$ from blue to green water flow. The synchronous climate variability caused an increase of green water flow by 469 million $^{3}$ and an increase of blue water flow by 146 million $^{3}$ at the river basin level, while the geographical distribution showed an uneven change even with reductions of water flows in western sub-basins at midstream. The results are helpful to benchmark the water resources in the context of global change in the inland river basins in China. This study also provides a general approach to investigate the impacts of historical human activities and climate variability on green and blue water flows at the river basin level.
\end{abstract}




\section{Introduction}

The impact of climate change on water availability has caused sustainability concerns around the world (Piao et al., 2010; Vörösmarty et al., 2000). With global warming, extreme weather events are now occurring more frequently, resulting in serious chal-

5 lenges to water supply (Vörösmarty et al., 2000, 2010; Oki and Kanae, 2006; Alley et al., 2003). Global climate change has already decreased water resources in many regions (Kundzewicz et al., 2008). In particular in arid regions, water use competition is intense among human, agriculture and ecosystems (Cheng et al., 2003; Vörösmarty et al., 2000). This influences socioeconomic sustainability and ecosystem health, and

10 may lead to ecosystem degradation (Piao et al., 2010; Falkenmark et al., 2003; Cheng et al., 2006). Therefore, a comprehensive study on the available water resources in the context of global change is critical for an in-depth understanding of the variability of water resources for better water resources management.

In recent years, scholars have paid much attention to blue water resources assess-

15 ment and management, but they have not paid sufficient attention to green water that is important for both human and ecosystems (Falkenmark, 1995; Cheng et al., 2006). Blue water is the water that is stored in rivers, lakes, aquifers and wetlands, while green water refers to the soil water from precipitation that is used for plant transpiration and soil evaporation (Falkenmark, 1995). Green water plays a critical role in produc-

20 ing food and maintaining natural ecosystems (Falkenmark et al., 1995, 2006). Rost et al. (2008) and Liu et al. (2009a, b) estimated green water accounted for more than $80 \%$ of consumptive water use of global crop production. Furthermore, water use in other ecosystems (e.g. grassland and forest ecosystems) is dominated by green water (Rockström, 1999; Rost et al., 2008).

25 Water resources in a catchment is influenced not only by climate change but also by activities of humans (Wang et al., 2005). Actually, there is interaction among climate factors, human activities and water resources. Water vapour cycling is a critical part of the climate system; and climate change will also influence the spatial and temporal

9479

variability of water resources in a watershed (Chen et al., 2007; Ren, 2011). On the one hand, human activities (e.g. land use change and irrigation) will change the discharge generation mechanism; on the other hand, human activities (e.g. greenhouse gas emissions) will trigger global or regional warming, consequently influencing water 5 resources distribution (Siriwarden et al., 2006; Thamapark et al., 2006). The impacts of human activities and climate factors may cause a water shortage or crisis, especially in arid and semi-arid regions (Xiao et al., 2004). Therefore, assessments of the joint impacts of human activities and climate variability and trends on water resources are needed to understand green and blue water variability and sustainability of freshwater use in arid regions.

Recently, several studies have investigated the impacts on water resources of human activities, including land use change (Postel et al., 1996; Gerten et al., 2008; Jewitt et al., 2008; Liu et al., 2009), water conservancy projects (Hayashi et al., 2008; Liu et al., 2013), and irrigation (Allen et al., 1998; Wang et al., 2003). Li et al. (1998) found 15 that human activities mainly in terms of irrigation decreased runoff in downstream locations of the Tarim River Basin. Fang et al. (2001) found that the groundwater table declined and land subsidence had happened in several cities in the northern part of China due to groundwater over-exploitation. Williams (2009) estimated that water conservancy projects caused runoff to decrease by more than $55 \%$ in the Nile River Basin.

20 And Wang et al. (2003) found that cropland irrigation decreased runoff and changed overall water flows in the Hexi corridor (Heihe river basin, China). However, how human activities and climate factors synchronously impact on both green and blue water flow and their spatial distribution remains a rarely studied issue. In addition, many studies emphasize global change impacts on water resources in the future by establishing 25 future scenarios (Xu et al., 2003; Wei et al., 2009), but few focus on the past.

In this study, we investigated the impacts of three main processes, i.e. land use change, irrigation expansion and climate variability, on the flows of green and blue water in the Heihe river basin over the period 1986 to 2005 . Based on these results, we discuss implications for future research and water management. The Heihe river basin 
is the second-largest inland river basin in China. It is located in the northwest of China, and it has suffered from a serious water crisis in recent years (Cheng et al., 2003, 2006). Following the socio-economic development, water use in the midstream has increased sharply (Ma et al., 2011), and recently, human activities have changed the

5 distribution of lakes and watershed and the inter-annual allocation of water resources in the Heihe basin (Xiao et al., 2004). So far, no efforts have been paid to the assessment of green and blue water in the context of global change. We here investigate the green and blue water dynamics and their natural and anthropogenic causes.

\section{Methodology}

\section{$10 \quad 2.1$ The study area}

The Heihe river originates in the Qilian Mountains, and discharges into the Juyanhai Lake. The area of the basin is 0.24 million $\mathrm{km}^{2}$, with the majority located in China and a minor part in Mongolia (Fig. 1). The basin has an average altitude of over $1200 \mathrm{~m}$ with a length of $821 \mathrm{~km}$ for the major channel. Three sections are often distinguished:

15 upstream from the Qilian Mountain to the Yingluo Canyon, midstream running from the Yingluo to Zhengyi Canyon, and downstream terminating in the Juyanhai Lake (Fig. 1). The average annual air temperature is $2-3^{\circ} \mathrm{C}$ in the upstream, $6-8^{\circ} \mathrm{C}$ in the midstream, and $8-10^{\circ} \mathrm{C}$ in the downstream area. The average annual precipitation is $200-500 \mathrm{~mm}$ in upstream, $120-200 \mathrm{~mm}$ in midstream, and $<50 \mathrm{~mm}$ in most downstream regions

20 (Cheng et al., 2003). The potential evaporation ranges from $1000 \mathrm{~mm} \mathrm{yr}^{-1}$ in the upstream to $4000 \mathrm{~mm} \mathrm{yr}^{-1}$ in the downstream area (Li, 2009). Precipitation occurs mainly in summer and autumn (> $70 \%$ of annual precipitation between May and August; Ma et al., 2011), whereas spring is dry with snow and ice melting (4\% of total discharge; $\mathrm{Li}, 2009$ ); there is much snow in winter (Cheng et al., 2003). The river discharge pro-

25 vides about $65 \%$ of the blue irrigation water in midstream regions, while groundwater provides over $90 \%$ in the downstream regions (Xiao et al., 2011). The main land cover

9481

types of the basin include desert (prevailing downstream), mountains (upstream) and oases (midstream); these three land covers together account for $98.6 \%$ of the total basin area (Cheng, 2003).

\subsection{Simulation experiments}

5 To study climatic and anthropogenic impacts on green and blue water resources in the Heihe basin, we set up four simulation experiments as follows: scenario $A$ fixes land use and climate conditions around 1986 (land use in 1986 and climate for 1984-1986); scenario $B$ uses land use in 1986 and climate conditions for 2004-2006; scenario $C$ uses land use in 2005 and climate conditions for 2004-2006; scenario $D$ assumes all crops are irrigated in addition to scenario C (Fig. 2). Based on these scenarios, we analyse the impacts on green and blue water flows of climate variability (difference between $B$ and $A$ ), land use change (difference between $C$ and $B$ ), irrigation expansion (difference between $D$ and $C$ ) and all factors (difference between $D$ and $A$ ), respectively.

\subsection{The SWAT model}

15 In this study, we used the Soil and Water Assessment Tool (SWAT) to simulate green and blue water flow for the river basin of Heihe. The SWAT model is a semi-distributed water assessment model (Neitsch et al., 2004), which has been applied widely in different regions across the world (e.g. Schuol et al., 2008; Faramazi et al., 2009). We select the SWAT model for this study mainly due to two reasons. Firstly, it has been 20 successfully used for assessments of water cycling processes under different environmental conditions (Faramazi et al., 2009; Schuol et al., 2008; Gassman et al., 2007); and secondly, it has been successfully tested to simulate hydrological processes in the Heihe river basin (Huang et al., 2004; Li et al., 2009), including the green and blue water flows (Zang et al., 2012).

25 We use the version of SWAT-2005 that works in Arcview-3.3. The study area was separated into 309 hydrological response units (HRUs) and 32 sub-basins with 
information on topography, land use type, soil attributes, and management. Evapotranspiration was estimated by the Hargreaves method (Hargreaves et al., 1985), surface runoff was calculated with an SCS Curve Number (CN) method (Neitsch et al., 2004), while snowmelt was computed by an energy balance approach (Neitsch et al., 2004).

5 The actual evapotranspiration includes plant transpiration and soil evaporation. The SWAT model first calculates rainfall interception by plant canopy, then the maximum plant transpiration and soil evaporation using an approach similar to Ritchie (1972). The actual plant transpiration and soil evaporation are then calculated based on the soil moisture balance following Neitsch et al. (2004). The land use types influence

10 surface runoff generation rate and evapotranspiration. In SWAT, different land cover types (urban, crop and forest) correspond to different parameters (e.g. for curve number) (Neitsch et al., 2004). Irrigation influences the discharge in water channels and transpiration of irrigated crop. We only worked on the part of the river basin located within China and did not include the Mongolia part due to the lack of data. We use the

15 SUFI-2 approach from the SWAT-CUP interface (Abbaspour et al., 2007) to optimize parameters. The Nash-Sutcliffe coefficient $\left(E_{\mathrm{ns}}\right)$ (Nash et al., 1970) and the coefficient of determination $\left(R^{2}\right)$ were used to evaluate the goodness of the calibration and validation process.

This study is an expansion of our previous research. In Zang et al. (2012), we as-

20 sessed the spatial and temporal distribution of the water flows of green and blue only under natural conditions, i.e. without considering human activities. The SWAT model was calibrated to simulate the green and blue water flows at the whole-basin level by using climate data from 1980 to 2004 and land use data for 2000 (Zang et al., 2012). The calibration and validation processes were performed successfully, as shown by 25 high values of $E_{\mathrm{ns}}(>0.87)$ and $R^{2}(>0.9)$. Further information on the model simulation, parameters, calibration, and validation can be found in Zang et al. (2012). In the present study, we used the calibrated parameters derived from the previous study, and further investigated the impacts of human activities (land use change and irrigation expansion) and climate variability on the green and blue water flows. The impacts are

9483

assessed by comparing results from different scenarios with those under natural conditions. We expand the study period to cover 1978-2005, and land use maps for 1986 and 2005 are used in addition to that for 2000 in previous research.

\subsection{Green and blue water flow and data}

5 The actual evapotranspiration is green water flow, whereas the sum of surface runoff, lateral flows, and groundwater recharge is treated as blue water flow (Schuol et al., 2008). To account for the relative importance of the two flows, we defined the green water coefficient (GWC) as the ratio of green water flow to the total flow (green and blue water flows) (Liu et al., 2009a). The relative change rate $\left(\mathrm{RCR}=\left[\left(V_{i}-V_{0}\right) / V_{0}\right] \times 100 \%\right)$

10 was applied to indicate the relative change of a variable. $V$ refers to a variable (e.g. green water flow), 0 indicates the initial time period, and $i$ the ending time period.

The data on daily climate, DEM and land use in 1986 were obtained from the Heihe Data Research Group (HDRG) (http://westdc.geodata.cn). We used climate data between 1980 and 2005 from 19 weather stations for our simulation: 7 up-

15 stream, 7 midstream, and 5 downstream stations. The irrigation area, irrigation depth, and irrigation parameters that need input the SWAT model were obtained from published literature (Ge et al., 2011; Wang et al., 2012) and the Ministry of Water Resources irrigation test web site (http://www.syzz.org.cn/about.asp?id=23). The irrigation districts data were obtained from the HDRG (http://westdc.geodata.cn), and the

20 total irrigation area in the river basin is 1.88 million ha. In scenario $D$, we assume that all cropland within the irrigation districts is irrigated. The $1 \mathrm{~km}$ land use data for 1985 and 2005 were obtained from the institute of Geographic Science and Nature Resources Research, Chinese Academy of Sciences (CAS) (http://www.geodata. $\mathrm{cn} /$ Portal/aboutWebsite/aboutus.jsp? isCookieChecked=true) (see Table 2 for land use

25 types). The soil data were obtained from the Harmonized World Soil Database (HWSD) (http://www.iiasa.ac.at) with a spatial resolution of about $1 \mathrm{~km}$. This dataset includes 63 soil types for the Heihe river basin, and for each soil type soil parameters for two soil layers are available, i.e. $0-30 \mathrm{~cm}$ and $30-100 \mathrm{~cm}$. 


\section{Results}

\subsection{Impact of land use change}

Impacts of land use change are assessed by comparing difference of results from land use in 1986 and 2005 (holding all other factors unchanged). According to our model 5 simulation results (Table 1), at the river basin level, land use change has resulted in an increase of blue water flow by 206 million $^{3}$ and a concurrent increase in green water flow by the same amount. These changes are simulated in particular for the midstream and a part of the downstream region (Figs. 4 and 5). The relative change rate in the sub-basins there was more than $50 \%$ (Fig. 3). Irrigation water use and urban land use

10 are the two main reasons that caused the hydrological variability in the SWAT model (Neitsch et al., 2004). In this section, the main reason for these changes was, that urbanization expanded fast in these sub-basins (Fig. 4; Table 2), accelerating surface runoff production. In our simulations, the total green and blue water flow did not change in response to the land use changes, but the green water coefficient is found to have 15 decreased from $81-90 \%$ to $71-75 \%$, in particular in the middle part of midstream (Fig. 7).

\subsection{Impact of irrigation expansion}

At the river basin level, irrigation expansion resulted in a decrease of blue water flow by 66 million $\mathrm{m}^{3}$, according to our model (Table 1). Blue water flow decreased in particular

20 in midstream regions (Fig. 3), where a large area of agriculture with many irrigation farmlands exists (Fig. 4). In an earlier study, irrigation expansion was shown to require a large amount of water from rivers and groundwater (Wang et al., 2003). Green water flow has increased by the same amount due to farmland irrigation (Fig. 5), because, compared to rainfed agriculture, irrigated agriculture consumed more water and thus

25 increased actual evapotranspiration. As in the case of the isolated land use change effect, the total green and blue water flow did not change at the river basin level due

9485

to irrigation expansion, and the green water coefficient has increased from $71-75 \%$ to $81-90 \%$ in particular in the eastern part of the midstream area (Fig. 7).

\subsection{Impact of climate variability}

Climate variability, assessed as the difference between the mid-1980s and the mid5 2000s, has increased both blue and green water flow by 146 and 469 million $\mathrm{m}^{3}$, respectively (Table 1), with little change in the green water coefficient (87-88\%). Spatially, although climate variability has led to an increase in blue and green water flows in most sub-basins, we can also find a clear decreasing trend of both flows in the western part of the midstream. The decrease was a result of a lower precipitation in the western midstream area, where precipitation has decreased significantly at $p<0.10$ level from 1980 to 2005 (Fig. 8). Precipitation had increased in downstream areas; hence, blue and green water flows have increased there (Fig. 8).

\subsection{Impact of all factors}

In response to climate, land use and irrigation change, blue water flow has increased by 15286 million $\mathrm{m}^{3}$ in the entire river basin (Table 1). The spatial distribution of the changes in blue water flow varies largely, with decreases in western sub-basins, but increases in eastern sub-basins in midstream areas. The relative change rate of several midstream sub-basins exceeded $30 \%$ (Fig. 3). The change patterns were found to be largely influenced by climate variability; for example, in the western part of midstream areas,

20 precipitation showed a decreasing trend (Fig. 8); hence, both blue and green water flows decreased, though also influenced by other factors. As shown above, the accelerated urbanization and farmland irrigation are the other main reason that caused blue water flow variability, the increase of blue water flow probably influenced by urbanization development, and the decrease by irrigation expansion (Wang et al., 2003; Ma

25 et al., 2008). Therefore, land use change contributed most to this increase, followed by the contribution from climate variability (Table 1). 
Green water flow showed an increasing trend with a 329 million $\mathrm{m}^{3}$ higher flow over the entire river basin, mainly due to climate variability but also due to irrigation expansion (Table 1). Decreases (> 30\%) are found to prevail in most midstream sub-basins, while increases were simulated for most of sub-basins downstream (Fig. 5). The total

5 water flows increased by 615 million $\mathrm{m}^{3}$, caused almost exclusively by climate variability. Both land use change and irrigation expansion did not alter the amount of total water flows; instead, they influenced the allocation of water into green or blue flows.

\section{Discussion}

In this study, we applied the SWAT model to analyze the impacts of human activities

10 and climate variability on green and blue water flows for an arid river basin in a spatially explicit way. We choose two time periods (around 1986 and around 2005) to analyze the green and blue water flow variability because these two periods reflect the sharp socio-economic changes in the past decades. Land use change and irrigation were used as indicators for human activities. The land use change was found to be a main

15 factor that influences water resources variability. Between 1986 and 2005, the urban area has increased by $47 \%$, and the irrigated land had increased by $27 \%$ (Table 2 ).

The total water flows have increased in the past $20 \mathrm{yr}$ in the Heihe river basin, mainly as a result of increasing precipitation (Wu et al., 2010). However, land use changes - especially the urbanisation in the basin's midstream area - also have demonstrably

20 led to increased blue water flow. Urban construction hardens the ground, decreases soil infiltration, and accelerates surface runoff generation (Ren et al., 2002; Hao et al., 2008); hence, it increases blue water flow. Meanwhile, the increasing runoff and the decreasing infiltration rate would reduce the soil moisture for evapotranspiration; hence, green water flow was reduced (Wouter et al., 2006; Ma et al., 2008). At the same time, 25 cropland irrigation has caused green water flow to increase by 66 million $^{3}$, and blue water flow to decrease by the same quantities (Table 1). On the one hand, irrigation from watercourses would decrease the river discharge; on the other hand, farmland 9487

irrigation would increase the water availability for crop evapotranspiration (Allen et al., 1998; Andrew et al., 2009).

The results imply that land use change towards urbanization has led to a major shift from green to blue water flow in the study area, while irrigation expansion had resulted 5 in a shift from blue to green water flow. The transformation processes from blue to green water are as follows: blue water is brought through irrigation to crops or plants in different ecosystems and eventually evapotranspired as green water in terms of surface water evaporation and plant transpiration. The transformation processes from green to blue water are as follows: infiltration rate becomes smaller due to land use change e.g. 10 with more urban areas; hence, less water flow can get to unsaturated soils but terminates in water bodies in terms of surface runoff. Actually, as the hydrological processes are very complex, we cannot define the accurate transformation processes between green and blue water flow by one model (SWAT). The green and blue water transformation is a multi-directional loop system, but the model represents one-direction flow processes only with no feedback to the atmosphere (Neitsch et al., 2004). Further research is needed to study the mechanism of green and blue water mutual transformation, especially to strengthen the research of local water vapour cycle contributions to green and blue water transformation. Moreover, the limited number and uneven distribution of weather stations represent an important source that influences the accuracy

20 of results. Also, previously we have validated the runoff based on measured data (Zang et al., 2012); however, a lack of measured evapotranspiration hinders a validation for green water flow.

Our results provide insights into the impacts of climatic and human factors on green and blue water variability throughout the Heihe river basin and can help policymakers

25 to better manage the water resources in the context of global and regional climate change. As for the green water coefficient, the decreasing trend due to urbanization and the increasing trend due to irrigation are likely to apply in other river basins as well, although the impact magnitudes will certainly differ among regions. Future studies will have to investigate this in an intercomparative mode for a selection of river basins 
where transformations of both blue and green water flows are likely to have taken place. The present study demonstrates a general scenario analysis approach to study the impacts of historical human activities and climate variability on green and blue water flows at the river basin level, which we hope can serve as a guideline for follow-up

5 studies for other river basins.

\section{Supplementary material related to this article is available online at: http://www.hydrol-earth-syst-sci-discuss.net/10/9477/2013/ hessd-10-9477-2013-supplement.zip.}

Acknowledgements. This study was supported by the International Science and Technology 10 Cooperation Program of the Ministry of Science and Technology of China (2012-DFA91530), the National Natural Science Foundation of China (NSFC; 91025009), the Projects of International Cooperation and Exchanges of NSFC (41161140353), the Special Fund for Forestry Scientific Research in the Public Interest (No. 201204204), the 1st Youth Excellent Talents Program of the Organization Department of the Central Committee of the CPC, and the Fun15 damental Research Funds for the Central Universities (TD-JC-2013-2). Many thanks for Cheng Guodong from the Cold Area and Drought Zone Environmental Conditions and Engineering Institute of the CAS, Zhang Yinglan from the National Natural Science Foundation, and Xiubin $\mathrm{Li}$, Ganlin Zhang, and Honglang Xiao for their help during our research. We also thank BMBF's German Fellowship Programme for S\&T to support Junguo Liu's visit to Potsdam Institutes of Climate Change Impacts (PIK) in Germany.

\section{References}

Abbaspour, K. C.: User Manual for SWAT-CUP, SWAT Calibration and Uncertainty Analysis Programs, Swiss Federal Institute of Aquatic Science and Technology, Eawag, Duebendorf, Switzerland, 93 pp., 2007.

5 Allen, R. G., Periera, L. S., and Smith, M.: Crops Evapotranspiration Guidelines for Computing Crop Water Requirements, Paper 56, FAO Irrigation and Drainage, Roma, 1998.

Alley, R. B., Marotzke, J., and Nordhaus, W. D.: Abrupt climate change, Science, 299, 20052010, 2003.

Andrew, E. S. and Shashi, V.: Evapotranspiration of irrigated and rainfed maize-soybean cropping systems, Agr. Forest Meteorol., 149, 443-452, 2009.

Chen, Y. M., Li, W. H., Xu, C. C., and Hao, X. M.: Effects of climate change on water resources in Tarim River Basin, Northwest China, J. Environ. Sci., 19, 488-493, 2007.

Cheng, G. D.: Study on the sustainable development in Heihe river watershed from the view of ecological economics, J. Glaciol. Geocryol., 24, 335-344, 2003.

15 Cheng, G. D. and Zhao, L. Z.: Green water and its research progresses, Adv. Earth Sci., 21, 221-227, 2006.

Falkenmark, M.: Freshwater as shared between society and ecosystems: from divided approaches to integrated challenges, Philos. T. R. Soc. Lond. B, 358, 2037-2049, 2003.

Falkenmark, M. and Rockström, J.: The new blue and green water paradigm: breaking new ground for water resources planning and management, J. Water Resour. Plan. Manage., 132, 129-132, 2006.

Fang, S. and Chen, X. L.: Groundwater exploitation caused the environmental problems and governance, Groundwater, 23, 8-11, 2001.

Faramarzi, M., Abbaspour, K. C., Schulin, R., and Yang, H.: Modelling blue and green water resources availability in Iran, Hydrol. Process., 23, 486-501, 2009.

Gassman, P. W., Reyes, M., Green, C. H., and Arnold, J. G.: The soil and water assessment tool: historical development, applications, and future directions, T. ASABE, 50, 1211-1250, 2007.

$\mathrm{Ge}, \mathrm{Y}$. C. and $\mathrm{Li}, \mathrm{X}$.: Design and implementation of water resources managemnet and decision 30 support system in the middle reaches of Heihe River, J. Glaciol. Geocryol., 33, 190-196, 2011. 
Gerten, D., Hoff, H., and Bondeau, A.: Contemporary "green" water flows: simulations with a dynamic global vegetation and water balance model, Phys. Chem. Earth, 30, 334-338, 2005.

Gerten, D., Rost, S., von Bloh, W., and Lucht, W.: Causes of change in 20th century global river discharge, Geophys. Res. Lett., 35, L20405, doi:10.1029/2008GL035258, 2008.

Gilbert, R. O.: Statistical Methods for Environmental Pollution Monitoring, Van Nostrand Reinhold, New York, 1987.

Hao, X. M., Chen, Y. N., and Xu, C. C.: Impacts of climate change and human activities on the surface runoff in the Tarim River basin over the last fifty years, Water Resour. Manag., 22, 1159-1171, 2008.

Hargreaves, G. L., Asce, A. M., Hargreaves, G. H., and Riley, J. P.: Agricultural benefits for Senegal River Basin, J. Irrigat. Drain. Eng., 111, 113-124, 1985.

Hayashi, S., Murakami, S., Xu, K. Q., and Watanabe, M.: Effect of the Three Gorges Dam Project on flood control in the Dongting Lake area, China, in a 1998-type flood, J. HydroEnviron. Res., 2, 148-165, 2008.

Huang, Q. H. and Zhang, W. C.: Improvement and application of GIS-based distributed SWAT hydrological modelling on high altitude, cold, semi-arid catchment of Heihe River Basin, China, Journal of Nanjing Forestry University (Natural Sciences Edition), 28, 22-26, 2004.

Jewitt, G. P. W., Garratt, J. A., and Calder, I. R.: Water resources planning and modelling tools

20 for the assessment of land use change in the Luvuvhu Catchment, South Africa, Phys. Chem. Earth, 15, 1233-1241, 2004

$\mathrm{Li}, \mathrm{X}$. and Zhou, H. F.: Sustainable utilization of water resources of Tarim River under the influence of human activities, Geogr. Res., 17, 171-177, 1998.

$\mathrm{Li}, \mathrm{Z}$. L.: Runoff simulation in the upper reaches of Heihe River Basin and uncertainty analysis in hydrological modelling, Doctor degree thesis of Beijing Normal University, 12-21, 2009.

Li, Z. L., Shao, Q. X., Xu, Z. X., and Cai, X. T.: Analysis of parameter uncertainty in semidistributed hydrological models using bootstrap method: a case study of SWAT model applied to Yingluoxia watershed in northwest China, J. Hydrol., 385, 76-83, 2010.

Liu, J. G. and Yang, H.: Spatially explicit assessment of global consumptive water uses in cropland: green and blue water, J. Hydrol., 384, 187-197, 2009a.

Liu, J. G., Zehnder, A. J. B., and Yang, H.: Global consumptive water use for crop production: the importance of green water and virtual water, Water Resour. Res., 45, 1-18, 2009b.

9491

Liu, J. G., Zang, C. F., and Tian, S. Y.: Water conservancy projects in China: achievements, challenges and way forward, Global Environ. Change, 23, 633-643, 2013.

Liu, X., Ren, L., Yuan, F., Singh, V. P., Fang, X., Yu, Z., and Zhang, W.: Quantifying the effect of land use and land cover changes on green water and blue water in northern part of China, Hydrol. Earth Syst. Sci., 13, 735-747, doi:10.5194/hess-13-735-2009, 2009.

Ma, W., Ma, Y., Hu, Z., Su, Z., Wang, J., and Ishikawa, H.: Estimating surface fluxes over middle and upper streams of the Heihe River Basin with ASTER imagery, Hydrol. Earth Syst. Sci., 15, 1403-1413, doi:10.5194/hess-15-1403-2011, 2011.

Ma, Z. M., Kang, S. Z., and Zhang, L.: Analysis of impacts of climate variability and human activity on stream flow for a river basin in arid region of northwest China, J. Hydrol., 352, 239-249, 2008.

Mann, H. B.: Non-parametric tests against trend, Econometrica, 13, 245-259, 1945.

Meehl, G. A., Zwiers, F., Evans, J., Knutson, T., and Mearns, L.: Trends in extreme weather and climate events: issues related to modelling extremes in projections of future climate change, B. Am. Meteorol. Soc., 81, 427-436, 2000.

Nash, J. E. and Sutcliffe, J. V.: River flow forecasting through conceptual models - Part I: a discussion of principles, J. Hydrol., 10, 282-290, 1970.

Neitsch, S. L., Arnold, J. G., Kiniry, R., and Williams, J. R.: Soil and Water Assessment Tool Input/Output File Documentation Version 2005, Grassland, Soil and Water Research Lab-

20 oratory Agriculture Research Services \& Black Land Research Centre Texas Agricultural Experiment Station, 2004.

Oki, T. and Kanae, S.: Global hydrological cycles and world water resources, Science, 313, 1068-1072, 2006.

Piao, S. L., Ciais, P. E., and Fang, J. Y.: The impacts of climate change on water resources and agriculture in China, Nature, 467, 43-51, 2010.

Postel, S. L., Daily, G. C., and Ehrlich, P. R.: Human appropriation of renewable fresh water, Science, 271, 785-788, 1996.

Ren, L. L., Wang, M. R., and Li, C. H.: Impacts of human activity on river runoff in the northern area of China, J. Hydrol., 261, 204-217, 2002.

30 Ren, Y. Z.: The Influence of Climate Change and Human Activities on Basin Water Resources and Cases Study, Dalian University of Technology doctoral dissertation, 5-21, 2011.

Rockstrtöm, J.: On farm green water estimates as a tool for increased food production in water scarcity regions, Phys. Chem. Earth B, 24, 375-383, 1999. 
Rost, S., Gerten, D., Bondeau, A., Lucht, W., and Rohwer, J.: Agricultural green and blue water consumption and its influence on the global water system, Water Resour. Res., 44, 1-17, 2008.

Ritchie, J. T.: Model for predicting evaporation from a row crop with incomplete cover, Water

5 Resour. Res., 8, 1204-1213, 1972.

Schuol, J., Abbaspour, K. C., Yang, H., and Srinivasan, R.: Modelling blue and green water availability in Africa, Water Resour. Res., 44, 1-18, 2008.

Siriwardena, L., Finlayson, B. L., and Me, M. T. A.: The impact of land use change on catchments hydrology in large catchments: the Comet River, Central Queens land, Australia, J. Hydrol., 326, 199-214, 2006.

Vörösmarty, C. J., Green, P., and Salisbury, J.: Global water resources: vulnerability from climate change and population growth, Science, 289, 284-288, 2000.

Vörösmarty, C. J., Mclntyre, P. B., Gessner, M. O., Duegeon, D., and Prusevich, A.: Global threats to human water security and river biodiversity, Nature, 467, 555-561, 2010.

15 Wang, G. X., Cheng, G. D., and Du, M. Y.: The impacts of human activity on hydrological processes in the arid zones of the Hexi Corridor, northwest China, in the past $50 \mathrm{yr}$, in: Water Resources Systems - Water Variability and Global Change (Proceedings of symposium HS02a held during IUGG2003 al Sapporo, July 2003), IAHS Publ. no. 280, 93-103, 2003.

Wang, H., Jia, Y. W., Wang, J. H., and Qin, D. Y.: Evolutionary laws of the Yellow river basin's water resources under the impact of human activity, J. Nat. Resour., 20, 157-162, 2005.

Wang, Y., Zhao, T. H., Li, B., and Fan, X. Y.: Affecting factors of farmers' willingness to adopt water-saving technology in northwest arid region of China - case study in middle reaches of Heihe River, Water Sav. Irrigat., 11, 50-54, 2012.

Wei, X., Conway, D., Lin, E., and Xu, Y. L.: Future cereal production in China: the interaction of climate change, water availability and socio-economic scenarios, Global Environ. Change, 19, 34-44, 2009.

Williams, M. A. J.: Human Impact on the Nile Basin: Past, Present, Future, Springer Science + Business Media B.V, Vol. 23, 771-777, 2009.

Wouter, B., Rolando, C., and Bert, D. B.: Human impact on the hydrology of the Andean pa'ramos, Earth-Sci. Rev., 79, 53-72, 2006.

Wu, J. K., Ding, Y., and Yang, X.: Spatial-temporal variability of stable isotopes in precipitation in the Heihe River Basin, North-western China, Environ. Earth Sci., 61, 1123-1134, 2010.

9493

Xiao, S. C. and Xiao, H. L.: The impact of human activity on the water environment of Heihe water basin in last century, J. Arid Land Resour. Environ., 18, 57-62, 2004.

Xiao, S. C., Xiao, H. L., Li, Y., and Yang, Y.: Water issues and integrated water resource management in Heihe River Basin in recent 50 yr, J. Desert Res., 31, 529-535, 2011.

$5 \mathrm{Xu}, \mathrm{Y}$., Ding, Y. H., and Zhao, Z. C.: A scenario of seasonal climate change of the 21 st century in Northwest China, Clim. Environ. Res., 8, 19-26, 2003.

Zang, C. F., Liu, J., van der Velde, M., and Kraxner, F.: Assessment of spatial and temporal patterns of green and blue water flows under natural conditions in inland river basins in Northwest China, Hydrol. Earth Syst. Sci., 16, 2859-2870, doi:10.5194/hess-16-2859-2012, 2012. 
Table 1. The increase or decrease of blue water flow, green water flow and total water flows due to land use change, irrigation expansion, climate variability and all the above factors combined in the Heihe river basin (million $\mathrm{m}^{3}$ ).

\begin{tabular}{lrrrr}
\hline Variables & Impact of land use change & Impact of irrigation expansion & Impact of climate variability & Impact of all factors \\
\hline Blue water flow & 206 & -66 & 146 & 286 \\
Green water flow & -206 & 66 & 469 & 329 \\
\hline Total water flows & 0 & 0 & 615 & 615 \\
\hline
\end{tabular}

9495

Table 2. The land use area $\left(\mathrm{km}^{2}\right)$ and relative change rate of the Heihe river basin from 1986.

\begin{tabular}{lrrr}
\hline Land type & Land area in 1986 & Land area in 2005 & Relative change rate from 1986 to 2005 \\
\hline Forest high & 1609 & 1848 & $15 \%$ \\
Forest middle & 3738 & 4187 & $12 \%$ \\
Forest low & 671 & 683 & $2 \%$ \\
Forest mixed & 53 & 24 & $-55 \%$ \\
Grass high & 4586 & 4813 & $5 \%$ \\
Grass middle & 7329 & 7402 & $1 \%$ \\
Grass low & 27173 & 2336 & $-14 \%$ \\
River & 171 & 136 & $-20 \%$ \\
Lake & 352 & 316 & $-10 \%$ \\
Reservoir & 87 & 67 & $-23 \%$ \\
Glacier & 184 & 181 & $-2 \%$ \\
River shoal & 785 & 422 & $-46 \%$ \\
Town & 75 & 110 & $47 \%$ \\
Village & 324 & 1245 & $-24 \%$ \\
Mining & 99 & 139 & $21 \%$ \\
Gobi and desert & 158 & $4 \%$ \\
Saline & 53516 & $-7 \%$ \\
Swamp & 6385 & 589 & $-13 \%$ \\
Bare land & 680 & 3829 & $-6 \%$ \\
Bare Rock & 4094 & 32378 & $-9 \%$ \\
Others & 35611 & 1371 & $9 \%$ \\
Dry land & 4408 & 6687 & $-15 \%$ \\
Irrigated land & 161 & & $27 \%$ \\
\hline & 5280 & &
\end{tabular}




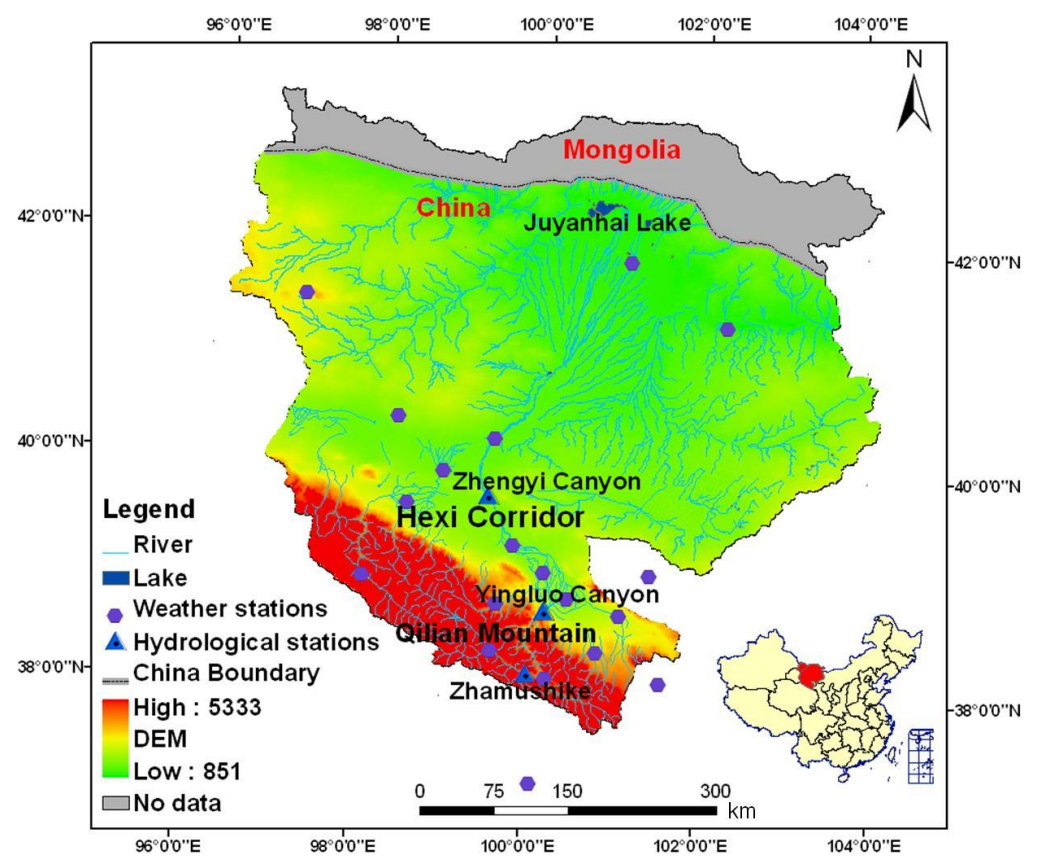

Fig. 1. The Heihe river basin with rivers, lakes, hydrological and weather stations indicated. The location of the Heihe river basin in China is shown in the inset.

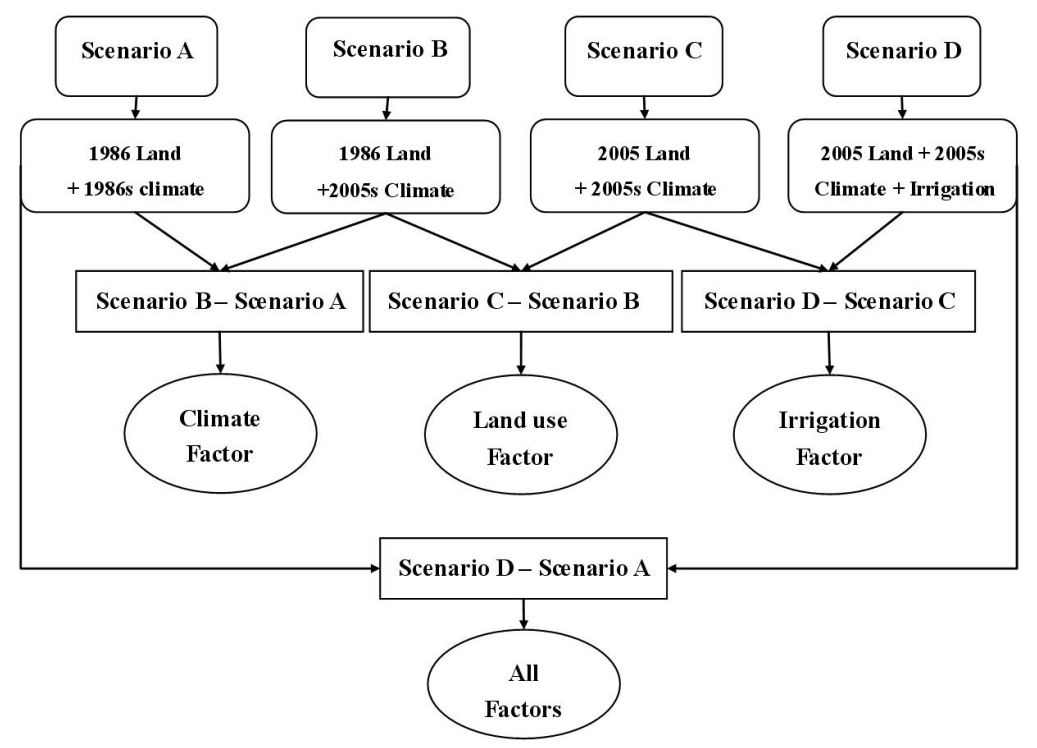

Fig. 2. The scenarios setup and research framework. 1986s is the average of 1984 to 1986 ; 2005 s is the average of 2004 to 2006. 


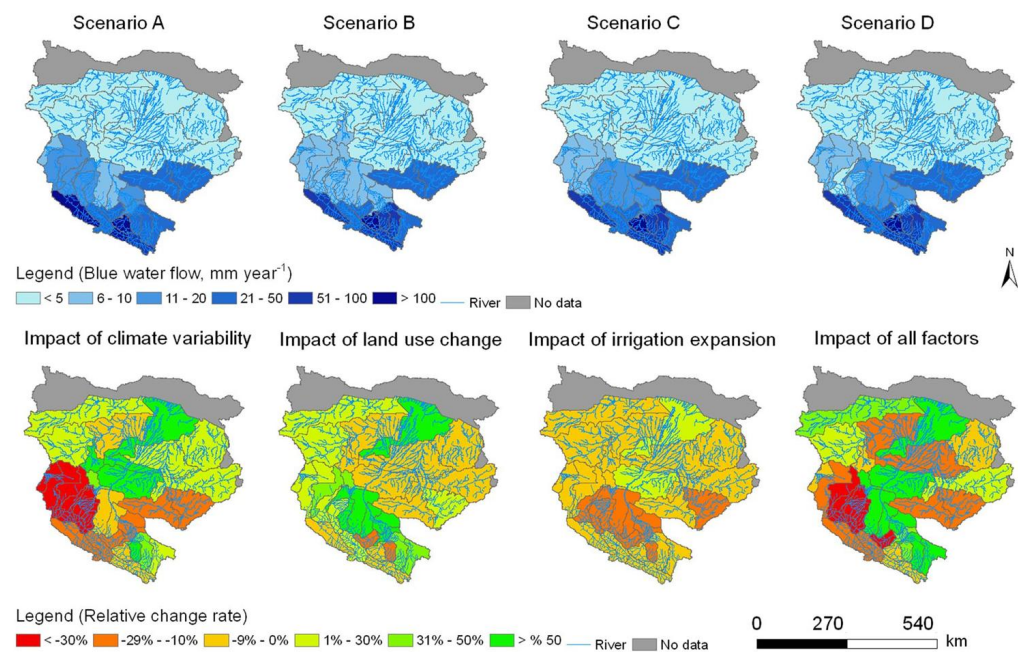

Fig. 3. The blue water flow in the Heihe river basin in different scenarios. The impacts are assessed with relative change rate. The impacts of climate variability, land use change and irrigation expansion are assessed by comparing results between Scenario B and A, Scenario $C$ and $B$, and Scenario $D$ and $C$, respectively. The impacts of all factors together are assessed by comparing results between Scenario $D$ and $A$.

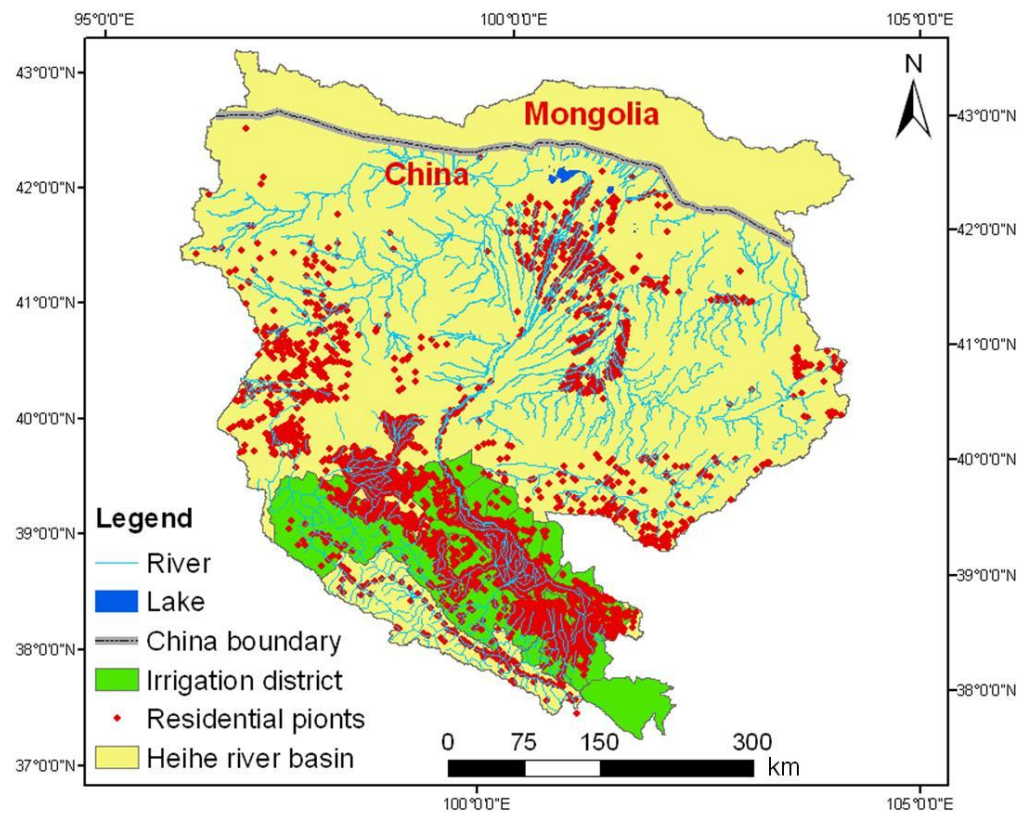

Fig. 4. The distribution of irrigation district and residential points in the Heihe river basin. 


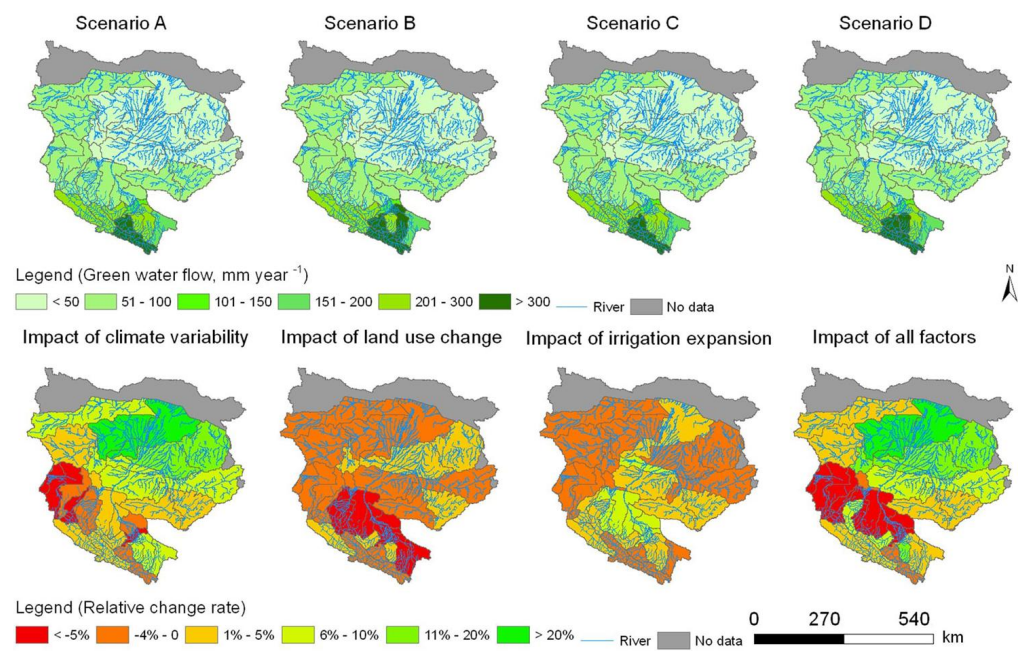

Fig. 5. The green water flow in the Heihe river basin in different scenarios. Details as in Fig. 3.

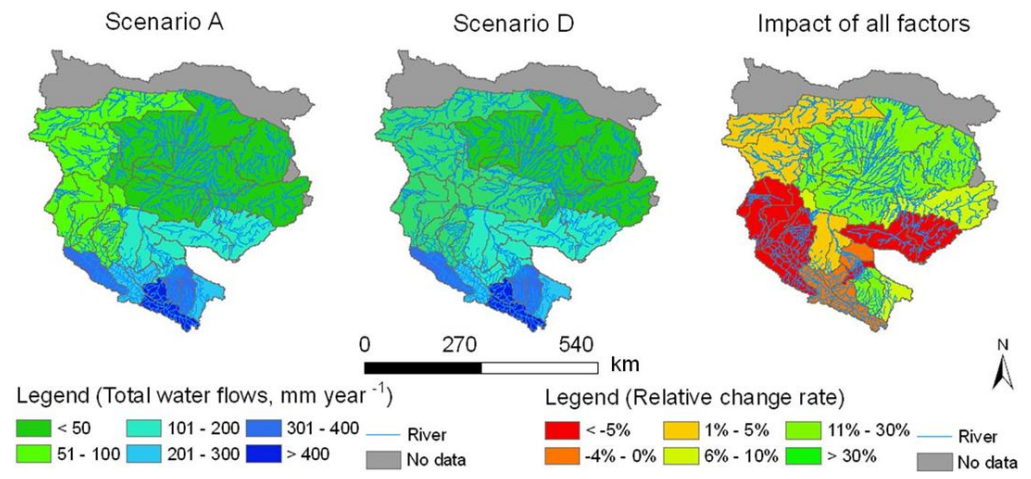

Fig. 6. Impacts of all factors (human activities and climate variability) on the total water flows in the Heihe river basin. 
Scenario A

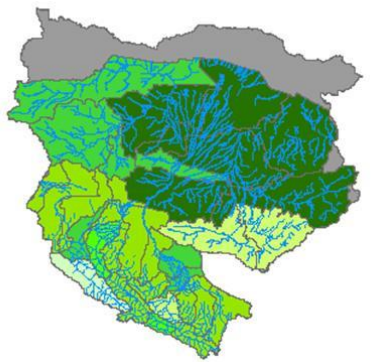

Scenario C

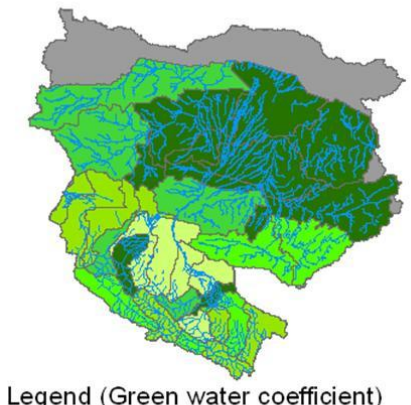

Scenario B

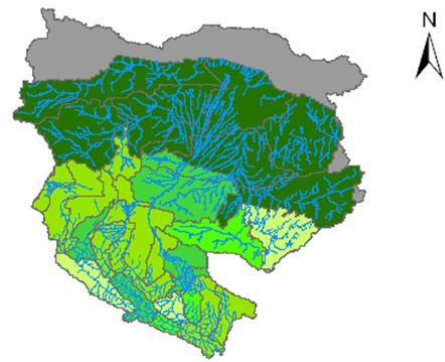

Scenario D

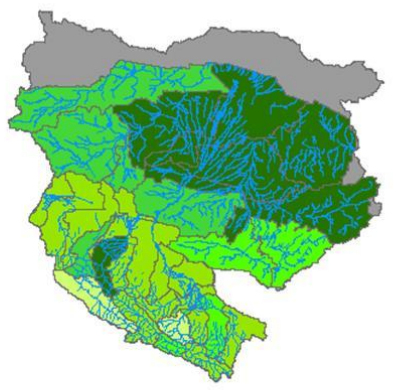

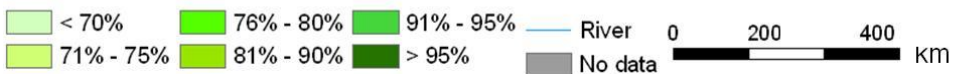

Fig. 7. The green water coefficient in the Heihe river basin in different scenarios.

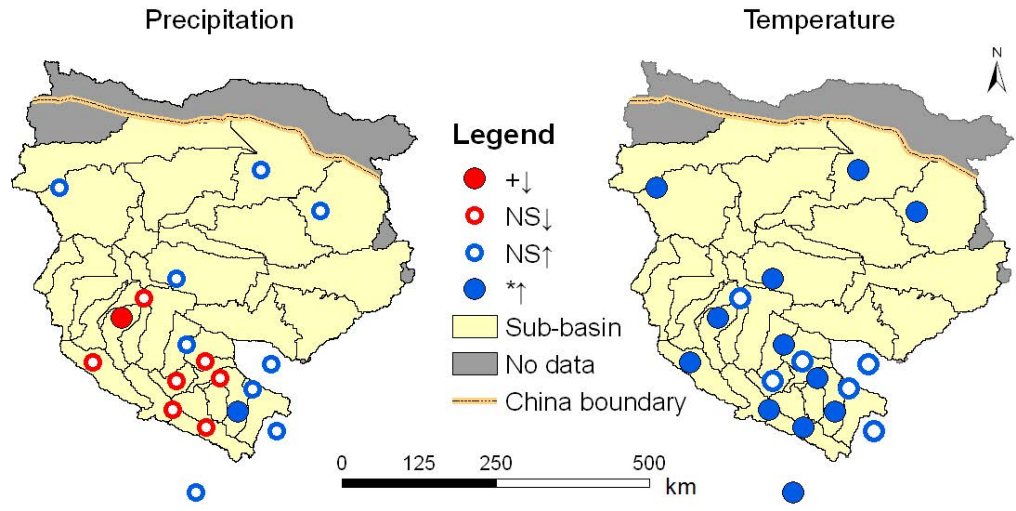

Fig. 8. The variability of precipitation and temperature in the Heine river basin from 1980 to 2005. $\uparrow$ indicates increasing trend; $\downarrow$ decreasing trend, ${ }^{*}$ significant at $p<0.05$; + significant at $p<0.10 ;$ NS, not significant. 